\title{
Laser drilling of alumina ceramics using solid state Nd:YAG laser and QCW fiber laser: Effect of process parameters on the hole geometry
}

\author{
Rihakova, L. ${ }^{\text {a, }},{ }^{*}$ Chmelickova, H. ${ }^{\text {b }}$ \\ ${ }^{a}$ Regional Centre of Advanced Technologies and Materials, Joint Laboratory of Optics of Palacký University and Institute of \\ Physics CAS, Faculty of Science, Palacký University, Olomouc, Czech Republic \\ boint Laboratory of Optics of Palacký University and Institute of Physics CAS, Faculty of Science, Palacký University, Olo- \\ mouc, Czech Republic
}

\begin{abstract}
A B S TR ACT
Nowadays a lot of lasers working at different parameters could be used for machining of a wide spectrum of materials. One of these materials is alumina ceramic as it is hard to machine using conventional methods due to high hardness and brittleness. In this paper the percussion drilling of alumina ceramics was performed by Nd:YAG laser and quasi-continuous-wave fiber laser. Effects of laser wavelength, pulse energy, pulse length and number of pulses were examined and the comparison of produced holes geometry was reported. The results show that it is possible to control the holes dimensions by changing lasers and parameters. Fiber laser provides generation of narrower holes due to its small spot and better beam quality together with high power densities. Shorter pulses $0.5 \mathrm{~ms}$, high peak power $1 \mathrm{~kW}$ and energy density around $10 \mathrm{~kJ} / \mathrm{cm}^{2}$ are satisfactory for drilling, as they assured good holes circularity and less amount of melt. For Nd:YAG laser it was found that both entrance and exit holes diameters go up proportionally with the pulse length and pulse energy. The optimum parameters for this laser were pulse length $1 \mathrm{~ms}$ as good circularity and less amount of dross was obtained, and energy densities around $1 \mathrm{~kJ} / \mathrm{cm}^{2}$ leading to formation of hole with better quality. Moreover, higher number of pulses improves holes circularity.
\end{abstract}

\section{ARTICLE INFO}

Keywords:

Alumina ceramics

Laser drilling

Solid state Nd:YAG laser

QCW fiber laser

Hole geometry

*Corresponding author:

lenka.rihakova@upol.cz

(Rihakova, L.)

Article history:

Received 17 July 2017

Revised 10 October 2017

Accepted 26 October 2017

\section{References}

[1] Preusch, F., Adelmann, B., Hellmann, R. (2014). Micromachining of $\mathrm{AlN}$ and $\mathrm{Al}_{2} \mathrm{O}_{3}$ using fiber laser, Micromachines, Vol. 5, No. 4, 1051-1060, doi: 10.3390/mi5041051.

[2] Samant, A.N., Dahotre, N.B. (2008). Computational predictions in single-dimensional laser machining of alumina, International Journal of Machine Tools and Manufacture, Vol. 48, No. 12-13, 1345-1353, doi: 10.1016/ j.ijmachtools.2008.05.004.

[3] Kim, S.H., Sohn, I.-B., Jeong, S. (2009). Ablation characteristics of aluminum oxide and nitride ceramics during femtosecond laser micromachining, Applied Surface Science, Vol. 255, No. 24, 9717-9720, doi: 10.1016/i.apsusc. 2009.04.058.

[4] Chang, C.-W., Kuo, C.-P. (2007). An investigation of laser-assisted machining of $\mathrm{Al}_{2} \mathrm{O}_{3}$ ceramics planning, International Journal of Machine Tools and Manufacture, Vol. 47, No. 3-4, 452-461, doi: 10.1016/j.ijmachtools.2006. $\underline{06.010 .}$.

[5] Salonitis, K., Stournaras, A., Tsoukantas, G., Stavropoulos, P., Chryssolouris, G. (2007). A theoretical and experimental investigation on limitations of pulsed laser drilling, Journal of Materials Processing Technology, Vol. 183, No. 1, 96-103, doi: 10.1016/i.jmatprotec.2006.09.031. 
[6] Hanon, M.M., Akman, E., Genc Oztoprak, B., Gunes, M., Taha, Z.A., Hajim, K.I., Kacar, E., Gundogdu, O., Demir, A. (2012). Experimental and theoretical investigation of the drilling of alumina ceramic using $\mathrm{Nd}$ : YAG pulsed laser, Optics \& Laser Technology, Vol. 44, No. 4, 913-922, doi: 10.1016/i.optlastec.2011.11.010.

[7] Ng, G.K.L., Li, L. (2001). The effect of laser peak power and pulse width on the hole geometry repeatability in laser percussion drilling, Optics \& Laser Technology, Vol. 33, No. 6, 393-402, doi: 10.1016/S0030-3992(01) 00048-2.

[8] Sibalija, T.V., Petronic, S.Z., Majstorovic, V.D., Prokic-Cvetkovic, R., Milosavljevic, A. (2011). Multi-response design of Nd: YAG laser drilling of Ni-based superalloy sheets using Taguchi's quality loss function, multivariate statistical methods and artificial intelligence, The International Journal of Advanced Manufacturing Technology, Vol. 54, No. 5-8, 537-552, doi: 10.1007/s00170-010-2945-3.

[9] Kacar, E., Mutlu, M., Akman, E., Demir, A., Candan, L., Canel, T., Gunay, V., Sinmazcelik, T. (2009). Characterization of the drilling alumina ceramic using Nd: YAG pulsed laser, Journal of Materials Processing Technology, Vol. 209, No. 4, 2008-2014, doi: 10.1016/i.jmatprotec.2008.04.049.

[10] Nedialkov, N.N., Atanasov, P.A., Sawczak, M., Sliwinski, G. (2003). Ablation of ceramics with ultraviolet, visible and infrared nanosecond laser pulses, In: Proceedings of XIV International Symposium on Gas Flow, Chemical Lasers, and High-Power Lasers, Wroclow, Poland, 703-708, doi: 10.1117/12.515847.

[11] Bharatish, A., Narasimha Murthy, H.N., Anand, B., Madhusoodana, C.D., Praveena, G.S., Krishna, M. (2013). Characterization of the hole circularity and heat affected zone in pulsed $\mathrm{CO}_{2}$ laser drilling of alumina ceramics, Optics \& Laser Technology, Vol. 53, 22-32, doi: 10.1016/j.optlastec.2013.04.010.

[12] Kononenko, T.V., Garnov, S.V., Klimentov, S.M., Konov, V.I., Loubnin, E.N., Dausinger, F., Raiber, A., Taut, C. (1997). Laser ablation of metals and ceramics in picosecond-nanosecond pulse width in the presence of different ambient atmospheres, Applied Surface Science, Vol. 109-110, 48-51, doi: 10.1016/S0169-4332(96)00905-1.

[13] Mendes, M., Sarrafi, R., Schoenly, J., Vangemert, R. (2015). Fiber laser micromachining in high-volume manufacturing, In: Proceedings of LPM2014 - the 15th International Symposium on Laser Precision Microfabrication, Vilnius, Lithuania.

[14] Petronić, S., Milosavljević, A., Radaković, Z., Drobnjak, P., Grujić, I. (2010). Analysis of geometrical characteristics of pulsed Nd: YAG laser drilled holes in superalloy NIMONIC 263 sheets, Tehnički Vjesnik - Technical Gazette, Vol. 17, No. 1, 61-66.

[15] Tunna, L., O’Neill, W., Khan, A., Sutcliffe, C. (2005). Analysis of laser micro drilled holes through aluminium for micro-manufacturing applications, Optics and Lasers in Engineering, Vol. 43, No. 9, 937-950, doi: 10.1016/ j.optlaseng.2004.11.001.

[16] Biswas, R., Kuar, A.S., Biswas, S.K., Mitra, S. (2010). Characterization of hole circularity in pulsed Nd: YAG laser

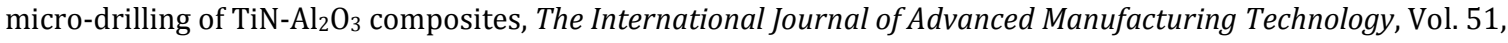
No. 9-12, 983-994, doi: 10.1007/s00170-010-2691-6.

[17] Mutlu, M., Kacar, E., Akman, E., Akkan, C.K., Demir, P., Demir, A. (2009). Effects of the laser wavelength on drilling process of ceramic using Nd: YAG laser, Journal of Laser Micro/Nanoengineering, Vol. 4, No. 2, 84-88, doi: $\underline{10.2961 / \mathrm{j} \operatorname{lmn} .2009 .02 .0002}$. 


\title{
Lasersko vrtanje aluminijeve keramike $z$ uporabo trdninskega laserja Nd:YAG in vlakenskega laserja QCW: učinek procesnih parametrov na geometrijo luknje
}

\author{
Rihakova, L. ${ }^{\text {a, }}{ }^{,}$, Chmelickova, H. ${ }^{\mathrm{b}}$ \\ ${ }^{a}$ Regional Centre of Advanced Technologies and Materials, Joint Laboratory of Optics of Palacký University and Institute of \\ Physics CAS, Faculty of Science, Palacký University, Olomouc, Czech Republic \\ boint Laboratory of Optics of Palacký University and Institute of Physics CAS, Faculty of Science, Palacký University, Olomo- \\ uc, Czech Republic
}

\begin{abstract}
POVZETEK
Danes je številne laserske naprave, ki delujejo pri različnih parametrih, mogoče uporabiti za obdelavo širokega spektra materialov. Eden od teh materialov je aluminijeva keramika (aluminijev oksid), ker ga je zaradi visoke trdote in krhkosti težko strojno obdelovati z običajnimi metodami. V prispevku je opisano udarno vrtanje aluminijeve keramike s trdninskim laserjem Nd: YAG in vlakenskim laserjem. Proučili smo učinek valovne dolžine laserja, energije impulza, dolžine impulza in števila impulzov na geometrijo izdelanih lukenj. Rezultati so pokazali, da je z izbiro laserja in spreminjanjem parametrov mogoče vplivati na dimenzijo luknje. Vlakenski laser omogoča izdelavo ozkih lukenj, kar je posledica majhnega premera in boljše kakovosti žarka z visoko gostoto moči. Krajši impulzi $0,5 \mathrm{~ms}$, visoka moč $1 \mathrm{~kW}$ in gostota energije okoli $10 \mathrm{~kJ} / \mathrm{cm} 2$ so primerni za vrtanje, saj zagotovijo dobro cilindričnost lukenj in majhno količino taline. Za laser Nd:YAG smo ugotovili, da se premera vhodnih in izstopnih lukenj povečujeta sorazmerno $\mathrm{z}$ dolžino in energijo impulza. Optimalni parametri za ta laser so: dolžina impulza $1 \mathrm{~ms}$, pri kateri je ugotovljena dobra cilindričnost, luknje pa vsebujejo manj srha; ter gostota energije okoli $1 \mathrm{~kJ} / \mathrm{cm} 2$, ki zagotavlja luknje z višjo kakovostjo. Večje število impulzov izboljša cilindričnost lukenj.
\end{abstract}

\section{PODATKI O ČLANKU}

Ključne besede: Aluminijeva keramika Lasersko vrtanje Trdninski laser Nd: YAG Vlakenski laser QCW Geometrija luknje

*Kontaktna oseba: lenka.rihakova@upol.cz (Rihakova, L.)

Zgodovina članka:

Prejet 17. julija 2017

Popravljen 10. oktobra 2017

Sprejet 26. oktobra 2017 